\title{
Glucose Utilization in Type 1 (Insulin-Dependent) Diabetes: Evidence for a Defect not Reversible by Acute Elevations of Insulin
}

\author{
J. Proietto ${ }^{1,2}$, A. Nankervis ${ }^{1,2}$, P. Aitken ${ }^{1}$, G. Caruso ${ }^{1}$ and F. Alford ${ }^{1,2}$ \\ ${ }^{1}$ Endocrine Unit and 2Department of Medicine, University of Melbourne, St. Vincent's Hospital Fitzroy, Victoria, Australia
}

\begin{abstract}
Summary. It has long been assumed that replacement of insulin in insulin-deficient diabetic patients will normalise glucose utilization. In this study, glucose utilization was measured in nine long-standing, poorly controlled diabetic patients and five control subjects, matched for age ( $33 \pm 3$ versus $33 \pm 2$ years) and ponderal index (22.9 \pm 1.3 versus $21.7 \pm 1.0)$. Glucose uptake was measured during steady state insulinaemia in the diabetic patients and control subjects, at euglycaemia $(5.5 \pm 0.5$ versus $5.4 \pm 0.3 \mathrm{mmol} / 1$, respectively) and moderate hyperglycaemia $(11.8 \pm 0.9$ versus $10.2 \pm 0.7 \mathrm{mmol} / 1$, respectively). At euglycaemia with similar free insulin levels $(50 \pm 19$ versus $43 \pm 9 \mathrm{mU} / 1 ; p>0.6$ ), the diabetic patients utilized less glucose than the control subjects $(27.8 \pm 4.2$ versus $56.4 \pm$ $\left.5.7 \mu \mathrm{mol} \cdot \mathrm{kg}^{-1} \cdot \mathrm{min}^{-1} ; \cdot p<0.005\right)$. During hyperglycaemia, the diabetic patients utilized almost as much glucose as the control subjects did at euglycaemia (49.9 \pm 6.4 versus $56.4 \pm$
\end{abstract}

$5.7 \mu \mathrm{mol} \cdot \mathrm{kg}^{-1} \cdot \mathrm{min}^{-1}$, respectively). In the control subjects, a $1-\mathrm{mmol} / \mathrm{l}$ rise in glucose concentration (with insulin remaining constant) resulted in a $12.3 \pm 1.3 \mu \mathrm{mol} \cdot \mathrm{kg}^{-1} \cdot \mathrm{min}^{-1}$ rise in glucose utilization. In contrast, in the diabetic patients, a $1-\mathrm{mmol} / 1$ rise in blood glucose resulted in a rise in glucose utilization of only $3.8 \pm 0.8 \mu \mathrm{mol} \cdot \mathrm{kg}^{-1} \cdot \mathrm{min}^{-1}(p<0.001)$, in the presence of similar concentrations of plasma insulin. This defect of glucose utilization in Type1 diabetic patients could not be reversed by acutely raising insulin to $247 \pm 23 \mathrm{mU} / 1$. It is concluded that poorly controlled, insulin-dependent diabetes has a marked defect in glucose utilization that cannot be corrected by short-term hyperinsulinaemia.

Key words: Type 1 diabetes, glucose utilization, insulin resistance.
Over 40 years ago, Soskin and Levine showed that the insulin-deficient, eviscerated-depancreatized dog utilized glucose at a reduced rate [1]. However, this defect in glucose utilization returned to normal when the blood glucose concentration was very high [2]. They surmised that the absence of insulin caused a defect in glucose utilization, which would be overcome either by hyperglycaemia (i.e. by increasing the glucose gradient) or by the acute administration of insulin [2]. It has been a long-standing tacit assumption that replacement of insulin in Type 1 (insulin-dependent) diabetic patients will return glucose utilization to normal. However, evidence is presented in this paper that in long-standing Type 1 diabetic patients on conventional treatment regimens, there is a defect in glucose utilization which persists in the presence of normal free insulin levels and cannot be corrected by acute hyperinsulinaemia.

\section{Materials and Methods}

\section{Subjects}

Experiments were performed on five normal subjects (four males and one female) and nine long-standing, Type 1 diabetic patients. Table 1 shows the relevant clinical data. The control and diabetic subjects were matched for age ( $32.8 \pm 2.0$ versus $32.8 \pm 3.0$ years) and ponderal index $(21.7 \pm 1.0$ versus $22.9 \pm 1.3)$ in control and diabetic subjects respectively. The diabetic subjects had had diabetes for a mean of $17 \pm$ 3 years and were on an average dose of $65 \mathrm{U}$ of insulin/day. The patients were selected from the diabetic clinic only on the criteria of duration of diabetes of $>5$ years, and absence of major diabetic complications, as assessed by absence of proliferative retinopathy, large vessel disease and proteinuria and the presence of normal plasma urea and creatinine concentrations. No special attempt was made to control their diabetes less well before the study. The mean glycosylated haemoglobin $\left(\mathrm{HbA}_{\mathrm{lc}}\right)$ level at the time of the study was $13.7 \pm 0.9 \%$ (normal 4.5\%-8.5\%). Written informed consent was obtained from all subjects, and the protocol was approved by the Ethics and Research Committee of St. Vincent's Hospital, Fitzroy.

\section{Study Protocol}

All subjects were studied after an overnight fast and at least a 30-min period of recumbency. The diabetic subjects had their last injection of long-acting insulin on the morning of the day before each study. On the morning of a study, euglycaemia was achieved in the diabetic patients, before the start of each experiment by a $2-4 \mathrm{~h}$ infusion of insulin $\left(75 \mathrm{mU} \cdot \mathrm{kg}^{-1} \cdot \mathrm{h}^{-1}\right)$. Once euglycaemic, the protocol as shown in Figure 1 was commenced. During the first $60 \mathrm{~min}$ of each period, the glucose infusion rate was varied to maintain euglycaemia (period 1) or hyperglycaemia (period 2). In order to inhibit endogenous insulin se- 
Table 1. Clinical details of the diabetic and control subjects

\begin{tabular}{|c|c|c|c|c|c|}
\hline $\begin{array}{l}\text { Diabetic } \\
\text { subjects }\end{array}$ & Sex & $\begin{array}{l}\text { Age } \\
\text { (years) }\end{array}$ & $\begin{array}{l}\text { Ponderal } \\
\text { index } \\
\text { weight }(\mathrm{kg}) \\
\text { height }^{2}(\mathrm{~m})\end{array}$ & $\begin{array}{l}\text { Duration } \\
\text { of diabetes } \\
\text { (years) }\end{array}$ & $\begin{array}{l}\text { Dose of } \\
\text { insulin (units) }\end{array}$ \\
\hline 1 & M & 22 & 22 & 9 & $\begin{array}{l}\text { NPH } 96 \\
\text { Regular } 12\end{array}$ \\
\hline 2 & M & 27 & 16 & 20 & $\begin{array}{l}\text { NPH } 36 \\
\text { Regular } 12\end{array}$ \\
\hline 3 & $\mathrm{~F}$ & 28 & 24 & 19 & Monotard 30 \\
\hline 4 & $\mathrm{~F}$ & 32 & 21 & 10 & $\begin{array}{l}\text { Leo } \\
\text { Retard } 44 \\
\text { Actrapid } 26\end{array}$ \\
\hline 5 & M & 39 & 22 & 24 & $\begin{array}{l}\text { Leo } \\
\text { Retard } 60\end{array}$ \\
\hline 6 & M & 23 & 22 & 6 & $\begin{array}{l}\text { NPH } 32 \\
\text { Regular } 12\end{array}$ \\
\hline 7 & M & 33 & 24 & 14 & Monotard 40 \\
\hline 8 & M & 41 & 24 & 17 & $\begin{array}{l}\text { Lente } 60 \\
\text { Actrapid } 4\end{array}$ \\
\hline 9 & M & 50 & 31 & 30 & NPH 100 \\
\hline $\begin{array}{l}\text { Mean } \pm \\
\text { SEM }\end{array}$ & $\begin{array}{l}7 \mathrm{M} \\
2 \mathrm{~F}\end{array}$ & $33 \pm 3$ & $23 \pm 1$ & $17 \pm 3$ & - \\
\hline $\begin{array}{l}\text { Control } \\
\text { subjects }\end{array}$ & $\begin{array}{l}4 \mathrm{M} \\
1 \mathrm{~F}\end{array}$ & $33 \pm 2$ & $22 \pm 1$ & - & - \\
\hline
\end{tabular}

cretion in the control subjects, somatostatin (Bachem, California, USA) was infused at $7.5 \mu \mathrm{g} / \mathrm{min}$. No somatostatin was necessary for the diabetic patients, as they had essentially no endogenous insulin (fasting C-peptide: $0.015 \pm 0.003 \mathrm{nmol} / 1$ compared with control subjects $0.30 \pm 0.044 \mathrm{nmol} / 1$; Table 2 ). Steady state plasma insulin levels were maintained throughout each study by fixed rates of insulin infusion (Table 2) ranging between $30-300 \mathrm{mU} \cdot \mathrm{kg}^{-1} \cdot \mathrm{h}^{-1}$ (Actrapid MC, Novo Laboratories, Sydney, Australia). In all studies, glucose utilization was measured at steady state, during euglycaemia (period 1), and moderate hyperglycaemia (period 2) (Fig. 1). Plasma glucose levels were adjusted by performing modified [3] euglycaemic and hyperglycaemic clamps [4]. During the hyperglycaemic period, urine was collected for measurement of urinary glucose loss.

All solutions were infused using Gilson Minipuls II pumps (Gilson, Villiers le Bel, France) via a $20 \mathrm{~cm}$ catheter placed in an antecubital vein. Blood samples were collected at appropriate intervals (Fig.1) from an indwelling butterfly needle placed in a contralateral arm vein. To overcome the problems of hormone adsorbing to the IV apparatus, insulin was pre-run for $1 \mathrm{~h}$ before use. Somatostatin was infused with $0.2 \%$ human serum albumin (Beringwerke, Mannheim, FRG) and $10000 \mathrm{KIU} / \mathrm{ml}$ of aprotinin (Trasylol, Bayer Pharmaceuticals, Sydney, Australia). Blood for hormone estimation was collected in $10 \%$ aprotinin, promptly centrifuged and plasma stored at $-20^{\circ} \mathrm{C}$.

In all diabetic subjects, the contribution of hepatic glucose production to the total rate of appearance of glucose was measured using a primed constant infusion of $\left[3{ }^{3} \mathrm{H}\right]$-glucose $[5,6]$. The priming dose of tracer varied between $15-35 \mu \mathrm{Ci}$ depending on the fasting plasma glucose (Sönksen $P$, personal communication). In the normal subjects, hepatic glucose production was assumed to be insignificant $(<$ $\left.2.2 \pm 0.8 \mu \mathrm{mol} \cdot \mathrm{kg}^{-1} \cdot \mathrm{min}^{-1}\right)$ at the insulin infusion rates employed $\left(25 \mathrm{mU} \cdot \mathrm{kg}^{-1} \cdot \mathrm{h}^{-1}\right)[5,7]$. In these subjects the rate of appearance of glucose equalled the rate of glucose infused intravenously.

Glucose was measured using a Union Carbide Centrifichem C400 analyser (Union Carbide Corporation, New York, USA) employing the hexokinase method. Plasma insulin (IRI) was estimated by radioimmunoassay employing dextran-charcoal separation of bound and free fractions [8]. Assay sensitivity for IRI was $1 \mathrm{mU} / 1$ with an interassay coefficient of variation at $10.5 \mathrm{mU} / 1$ of $6.3 \%$ and coefficient of variation at $22.0 \mathrm{mU} / 1$ of $8.4 \%$. In the diabetic subjects, free insulin
SOMATOSTATIN $7.5 \mathrm{\mu g} / \mathrm{min}$
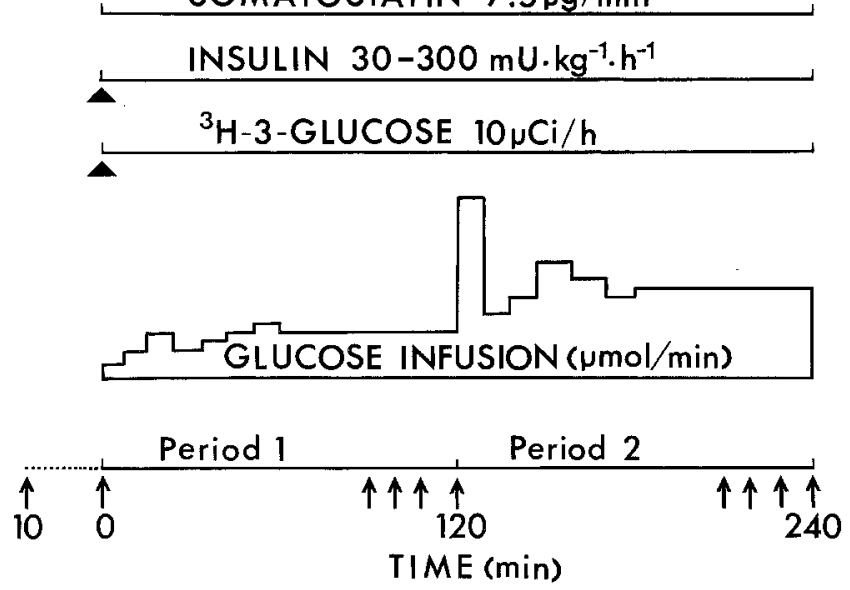

Fig. 1. Schematic diagram of the protocol used. Somatostatin was used only in the control subjects. The bolus dose $(\boldsymbol{\Delta})$ of $\left[3-{ }^{3} \mathrm{H}\right]$-glucose at the start of the study varied between $15-35 \mu \mathrm{Ci}$ depending on the fasting blood glucose level. During the first $60 \mathrm{~min}$ of each period, glucose infusion rate was varied to maintain euglycaemia (period 1) or hyperglycaemia (period 2). The arrows $(\uparrow$ ) indicate sampling times

was measured as described by Nakagawa et al. [9]. The correlation coefficients $(r)$ between the insulin infusion rates and the plasma insulin levels achieved at plateau, in diabetic subjects with circulating insulin antibodies and in normal subjects without insulin antibodies, were 0.94 and 0.97 respectively. C-peptide was estimated using the Novo C-peptide assay kit employing synthetic human C-peptide and guinea pig anti-human C-peptide antiserum [10]. Assay sensitivity for C-peptide was $0.01 \mathrm{nmol} / 1$ with an interassay coefficient of variation at $0.29 \mathrm{nmol} / 1$ of $11.4 \%$ and at $0.026 \mathrm{nmol} / 1$ of $24.6 \%$. Non-esterified fatty acids (NEFA) were measured using a modification of the method of Carruthers and Young [11] and $\beta$-hydroxybutyrate levels were estimated as described by Williamson et al. [12]. The relevant plasma samples from the $\left[3-\mathrm{H}^{3}\right]$-glucose tracer studies were processed as described previously [3].

\section{Calculations}

In the diabetic patients, the rate of appearance of glucose $(\mathrm{Ra})$ at steady state $=\mathrm{F} / \mathrm{SA}$ where $\mathrm{F}=$ the rate of infusion of $\left[3-\mathrm{H}^{3}\right]$-glucose and $\mathrm{SA}=$ the specific activity of the tracer. The mean coefficient of variation for tracer counts at plateau was $3.6 \pm 0.9 \%$. In three studies, steady state was not achieved (Table 2). In these, the non-steady state equation of Steele was used with 0.65 as the pool fraction [13]. In the control subjects, the rate of appearance of glucose at steady state equals the rate of glucose infused IV, since hepatic contribution to the rate of appearance of glucose is insignificant at the insulin infusion rates used $[5,7]$. At steady state, plasma glucose is constant, defined as a coefficient of variation of plasma glucose concentration about plateau of $<10 \%$. Mean coefficients of variation of glucose values at steady state were $4.5 \pm 0.7 \%$ for the euglycaemic and $4.2 \pm 0.7 \%$ for the hyperglycaemic periods. At steady state, the rate of appearance of glucose equals the rate of disappearance (Rd) and the rate of tissue glucose utilization ( $\mathrm{Ru}$ ) equals $\mathrm{Rd}$ minus urinary glucose loss. Urinary glucose loss during hyperglycaemia was $<0.2 \mu \mathrm{mol} \cdot \mathrm{kg}^{-1}$. $\mathrm{min}^{-1}$ in control subjects and $1.9 \pm 0.5 \mu \mathrm{mol} \cdot \mathrm{kg}^{-1} \cdot \mathrm{min}^{-1}$ in the diabetic subjects.

\section{Results}

Table 2 gives the data for plasma glucose, insulin infusion rates, free insulin and C-peptide levels, basally and 
Table 2. Data in the diabetic and control subjects

\begin{tabular}{|c|c|c|c|c|c|c|}
\hline \multicolumn{2}{|c|}{ Subject } & $\begin{array}{l}\text { Plasma } \\
\text { glucose } \\
(\mathrm{mmol} / 1)\end{array}$ & $\begin{array}{l}\text { Insulin } \\
\text { infusion } \\
\text { rate } \\
(\mathrm{mU} \text {. } \\
\mathrm{kg}^{-1} \text {. } \\
\mathrm{h}^{-1} \text { ) }\end{array}$ & $\begin{array}{l}\text { Plasma } \\
\text { free } \\
\text { insulin } \\
(\mathrm{mU} / \mathrm{l})\end{array}$ & C peptide & $\begin{array}{l}\text { Rate of } \\
\text { glucose } \\
\text { utiliza- } \\
\text { tion } \\
\text { ( } \mathrm{umol}^{-} \\
\mathrm{kg}^{-1} \text {. } \\
\mathrm{min}^{-1} \text { ) }\end{array}$ \\
\hline \multicolumn{7}{|c|}{ Diabetic patients } \\
\hline \multicolumn{7}{|c|}{ Low dose insulin infusion } \\
\hline \multirow[t]{3}{*}{1} & Basal & 14.5 & & 6 & 0.023 & - \\
\hline & E clamp & 6.2 & & 17 & 0.022 & 22 \\
\hline & H clamp & 11.9 & 30 & 20 & 0.022 & 30 \\
\hline \multirow[t]{3}{*}{2} & Basal & 17.6 & & 17 & 0.022 & - \\
\hline & E clamp & 7.7 & & 16 & 0.015 & 44 \\
\hline & H clamp & 15.9 & 30 & 21 & 0.022 & 59 \\
\hline \multirow[t]{3}{*}{3} & Basal & 19.0 & & 0 & 0.033 & - \\
\hline & E clamp & 5.7 & & 23 & 0.025 & 27 \\
\hline & H clamp & 14.9 & 30 & 20 & 0.025 & 55 \\
\hline \multirow[t]{3}{*}{4} & Basal & 14.5 & & 0 & 0.003 & - \\
\hline & E clamp & 4.5 & & 24 & 0.003 & 16 \\
\hline & H clamp & 8.7 & 30 & 25 & 0.003 & 36 \\
\hline \multirow[t]{3}{*}{5} & Basal & 3.1 & & 13 & 0.015 & - \\
\hline & E clamp & 3.7 & & 21 & 0.013 & 13 \\
\hline & H clamp & 10.8 & 30 & 24 & 0.015 & 36 \\
\hline \multirow[t]{3}{*}{6} & Basal & 16.5 & & 8 & 0.005 & - \\
\hline & E clamp & 5.8 & & 65 & 0.005 & 16 \\
\hline & H clamp & 9.2 & 75 & 68 & 0.005 & 36 \\
\hline \multirow[t]{3}{*}{7} & Basal & 27.0 & & 2 & 0.002 & - \\
\hline & E clamp & 7.1 & & 46 & 0.002 & 40 \\
\hline & H clamp & 13.7 & 75 & 47 & 0.004 & 45 \\
\hline \multirow[t]{3}{*}{8} & Basal & 6.5 & & 9 & 0.030 & - \\
\hline & E clampa & 4.0 & & 87 & 0.040 & 46 \\
\hline & H clamp & 9.5 & 75 & 84 & 0.025 & 92 \\
\hline \multirow[t]{3}{*}{9} & Basal & 15.8 & & 5 & 0.004 & - \\
\hline & E clamp & 5.1 & & 79 & 0.003 & 26 \\
\hline & H clamp & 11.5 & 75 & 81 & 0.004 & 60 \\
\hline \multicolumn{7}{|c|}{ High dose insulin infusion } \\
\hline \multirow[t]{3}{*}{1} & Basal & 20.0 & & 6 & - & - \\
\hline & E clamp ${ }^{2}$ & 3.5 & & 303 & - & 37 \\
\hline & H clamp & 10.2 & 300 & 310 & - & 56 \\
\hline \multirow[t]{3}{*}{3} & Basal & 22.8 & & 0 & - & - \\
\hline & E clamp & 4.6 & & 238 & - & 38 \\
\hline & H clamp & 10.4 & 250 & 213 & - & 65 \\
\hline \multirow[t]{3}{*}{4} & Basal & 19.2 & & 0 & - & - \\
\hline & E clamp & 5.5 & & 185 & - & 29 \\
\hline & H clamp & 11.4 & 300 & 137 & - & 68 \\
\hline \multirow[t]{3}{*}{6} & Basal & 17.0 & & 12 & - & - \\
\hline & E clamp ${ }^{\mathrm{a}}$ & 5.2 & & 295 & - & 44 \\
\hline & H clamp $p^{a}$ & 12.8 & 300 & 308 & - & 78 \\
\hline \multicolumn{7}{|c|}{ Control subjects $(n=5)$} \\
\hline & Basal & $4.8 \pm 0.1$ & & $5.5 \pm 0.8$ & $0.3 \pm 0.04$ & - \\
\hline & E clamp & $5.4 \pm 0.3$ & & $49 \pm 15$ & $0.03 \pm 0.01$ & $56 \pm 5.4$ \\
\hline & H clamp & $10.2 \pm 0.7$ & $47 \pm 8$ & $50 \pm 19$ & $0.08 \pm 0.03$ & $114 \pm 7.0$ \\
\hline
\end{tabular}

E clamp=euglycaemic clamp, $\mathbf{H}$ clamp=hyperglycaemic clamp. ${ }^{\text {a }}$ In these studies, steady state conditions were not achieved.

during each of the two study periods, together with the corresponding rates of utilization of glucose. Figure $2 \mathrm{~A}$ shows the mean rates of whole body glucose utilization during euglycaemia $(5.4 \pm 0.3$ versus $5.5 \pm 0.5 \mathrm{mmol} / 1)$ and moderate hyperglycaemia $(10.2 \pm 0.7$ versus $11.8 \pm$ $0.9 \mathrm{mmol} / 1 ; p>0.20$ in control and diabetic subjects respectively; Table 2). During euglycaemia, with comparable plasma free insulin concentrations $(50 \pm 19$ versus $43 \pm 9 \mathrm{mU} / 1 ; p>0.60$ in control and diabetic subjects respectively; Fig. $2 \mathrm{~A}$ ), the control subjects utilized twice as much glucose as the diabetic patients (56.4 \pm 5.7 versus $\left.27.8 \pm 4.2 \mu \mathrm{mol} \cdot \mathrm{kg}^{-1} \cdot \min ^{-1} ; p<0.005\right)$. Only

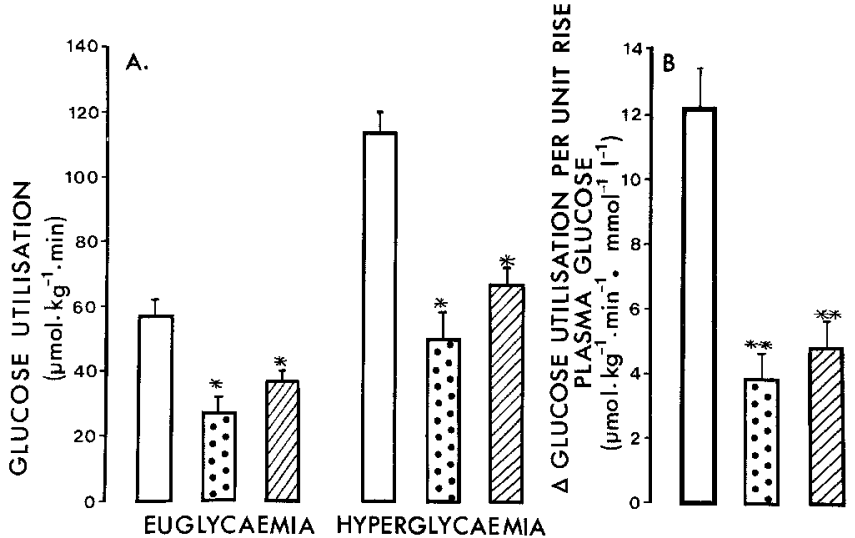

Fig. 2. Rate of glucose utilization (panel A) and the change in glucose utilization per unit rise in plasma glucose (panel B) in control subjects $(n=5)$ and diabetic subjects $(n=9)$ during euglycaemia and hyperglycaemia. Insulin levels in control subjects were $50 \pm 19 \mathrm{mU} / 1(\square)$ and in diabetic subjects $43 \pm 9$ (圆, $n=9$ ) and $247 \pm 23 \mathrm{mU} / 1($ (,$n=4)$. ${ }^{*} p<0.005$ and $* * p<0.001$ compared with the control group

during moderate hyperglycaemia did the diabetic patients utilize as much glucose as the control subjects at euglycaemia $\left(56.4 \pm 5.7\right.$ versus $49.9 \pm 6.4 \mu \mathrm{mol} \cdot \mathrm{kg}^{-1}$. $\min ^{-1} ; p>0.40$, Fig. $\left.2 \mathrm{~A}\right)$. However, it was again evident that the diabetic patients used very much less glucose than control subjects at hyperglycaemia $(49.9 \pm 6.4$ versus $\left.114 \pm 7.0 \mu \mathrm{mol} \cdot \mathrm{kg}^{-1} \cdot \mathrm{min}^{-1} ; p<0.005\right)$ despite similar free insulin levels in control and diabetic subjects (Fig. 2A).

To examine further the influence of plasma glucose concentration on the rate of tissue glucose utilization in the two groups, a comparison was made of the change in the rate of glucose utilization in response to a $1-\mathrm{mmol}$ rise in plasma glucose concentration, as shown in Fig. 2 B. This demonstrated the dramatically greater increase in the rate of glucose utilization in response to hyperglycaemia in controls compared to diabetics $\left(12.3 \pm 1.3\right.$ versus $3.8 \pm 0.8 \mu \mathrm{mol} \cdot \mathrm{kg}^{-1} \cdot \mathrm{min}^{-1}$. $\left.\mathrm{mmol}^{-1} \cdot 1^{-1} ; p<0.001\right)$ in the presence of similar concentrations of plasma insulin $(50 \pm 19$ versus $43 \pm$ $9 \mathrm{mU} / \mathrm{l}$ in control and diabetic subjects respectively).

To determine whether higher insulin levels could reverse the defect in glucose utilization present in the diabetic patients, experiments were repeated at higher insulin infusion rates in four of the diabetic subjects (Nos. 1, 3, 4, 6; Table 2). Figure $2 \mathrm{~A}$ shows the results obtained in these subjects at high levels $(247 \pm 23 \mathrm{mU} / \mathrm{l})$ insulin, compared to control subjects at low insulin levels $(50 \pm 19 \mathrm{mU} / \mathrm{l})$. When euglycaemia is maintained $(4.8 \pm 0.5 \mathrm{mmol} / 1)$ during high dose insulin experiments, the rate of glucose utilization rose significantly in the diabetic patients to $37.0 \pm 3.1 \mu \mathrm{mol} \cdot \mathrm{kg}^{-1} \cdot \mathrm{min}^{-1}$; $p<0.005)$ compared to the rate of glucose utilization obtained in diabetic subjects at low insulin levels $\left(27.8 \pm 4.2 \mu \mathrm{mol} \cdot \mathrm{kg}^{-1} \cdot \mathrm{min}^{-1}\right)$, but remained below the rate of utilization measured at the low insulin levels in normal subjects $\left(56.4 \pm 5.7 \mu \mathrm{mol} \cdot \mathrm{kg}^{-1} \cdot \mathrm{min}^{-1} ; p<0.05\right.$; 
Fig. 2A). During hyperglycaemia (10.7 $\pm 0.4 \mathrm{mmol} / 1)$ and the high insulin study, the rate of glucose uptake in the diabetic patients was $67 \pm 5 \mu \mathrm{mol} \cdot \mathrm{kg}^{-1} \cdot \mathrm{min}^{-1}$ ) which was significantly greater than that obtained in these diabetic subjects during the low insulin infusion $\left(27.8 \pm 4.2 \mu \mathrm{mol} \cdot \mathrm{kg}^{-1} \cdot \mathrm{min}^{-1} ; p<0.01\right.$; Fig. $\left.2 \mathrm{~A}\right)$. When the data are examined as the rate of change of glucose uptake per $1 \mathrm{mmol}$ rise in plasma glucose at high insulin levels (Fig. 2B), there was no significant improvement in the efficiency of glucose uptake in response to hyperglycaemia $\left(4.8 \pm 0.8 \mu \mathrm{mol} \cdot \mathrm{kg}^{-1} \cdot \mathrm{min}^{-1} \cdot \mathrm{mmol}^{-1} \cdot \mathrm{l}^{-1}\right)$ compared to glucose utilization at low insulin levels $\left(3.8 \pm 0.8 \mathrm{~mol} \cdot \mathrm{kg}^{-1} \cdot \mathrm{min}^{-1} \cdot \mathrm{mmol}^{-1} \cdot 1^{-1} ; \quad p>0.40\right.$; Fig. $2 \mathrm{~B}$ ). The rate of change of glucose utilization in the diabetic subjects remained strikingly below that observed for control subjects at low insulin levels (Fig. 2B).

From previous studies it could be assumed that with the insulin infusion rates used in the control subjects, hepatic glucose production would be insignificant $[3,5]$. This assumption could not be made for the diabetic patients and hepatic glucose production was measured in all the diabetic subjects. Hepatic glucose production was found to be low during both the euglycaemic and hyperglycaemic periods $(3.5 \pm 1.7$ and $3.0 \pm 1.9 \mu \mathrm{mol}$. $\mathrm{kg}^{-1} \cdot \mathrm{min}^{-1}$ respectively, $p>0.50$ ), and thus comprised $<17 \%$ and $<11 \%$ of overall glucose utilization in the diabetic subjects at euglycaemia and hyperglycaemia, respectively.

Following the attainment of euglycaemia and during the euglycaemic period (period 1, Fig. 1), NEFA levels were comparable in the two groups $(0.36 \pm$ $0.04 \mathrm{mmol} / 1$ (range $0.27-0.39$ ) versus $0.46 \pm 0.21$ $\mathrm{mmol} / 1$ (range $0.2-0.6$ ) in control and diabetic subjects respectively; $p>0.60$ ). Similarly, $\beta$-hydroxybutyrate levels were high in the diabetic patients before the start of the study $(0.77 \pm 0.24 \mathrm{mmol} / \mathrm{l})$, but fell to well within the normal range during the euglycaemic period (period 1 ; $0.04 \pm 0.02 \mathrm{mmol} / 1$ (range $0.01-0.09 \mathrm{mmol} / 1$ ); normal subjects $<0.17 \mathrm{mmol} / 1)$.

\section{Discussion}

This paper presents evidence that long standing, conventionally treated, insulin-requiring diabetic patients have a defect in glucose disposal, even in the presence of normal (Fig. 2) or high (Fig. 3) free insulin levels. Previous studies of glucose disposal in Type 1 diabetes are conflicting. Ginsberg could find no evidence of such a defect in a group of 12 newly diagnosed insulin dependent diabetics [14], whereas DeFronzo et al. have presented evidence of reduced glucose disposal in patients with long standing disease [15]. These findings, together with those described in this paper, suggest that the abnormality in glucose disposal develops after the onset of the illness and may thus be a consequence of the diabetic state itself.
The reason for the presence of this defect in glucose disposal is unclear. Studies in vivo using the euglycaemic clamp technique, measure the rate of total body glucose utilization [4, 7]. A decrease in glucose utilization can be related to an abnormality of glucose transport across the plasma membrane only if transport is the rate-limiting step. Similarly, an intracellular defect in a step of glucose metabolism, if rate-limiting, could also result in decreased glucose utilization. Thus, the reduced in vivo glucose uptake demonstrated in this study in the diabetic subjects, may be due either to a defect in glucose transport [16-18] and/or a defect in glucose metabolism [16, 18-20]. The diabetic subjects in this study were poorly controlled (as demonstrated by high $\mathrm{HbA}_{\mathrm{lc}}$ levels) and were on large doses of insulin (Table 1). Therefore these patients had adequate free insulin levels for most of the day [18], and the defect of glucose utilization in the diabetic subjects was not due to chronic insulin deficiency. Interestingly, in vitro glucose metabolism has also been reported to be reduced in adipocytes isolated from Type 1 diabetic patients [18]. An alternative explanation could be that elevated NEFA or ketone bodies, factors known to interfere with glucose metabolism and insulin action [21,22], contributed to the decrease in glucose utilization. However, both metabolites were normal in the diabetic subjects during the euglycaemic and hyperglycaemic sampling periods. Whatever the mechanism, it is clear that glucose utilization is abnormal in established insulin-dependent diabetes, even in the presence of adequate to high free insulin levels. It would be of considerable clinical interest to know if a sustained period of good diabetic control employing more physiological continuous insulin in delivery systems could reverse this defect.

The importance of the diminished glucose utilization to the pathogenesis of the hyperglycaemia in insulin-dependent diabetes is highlighted by the hepatic glucose production data. Glucose production was readily suppressed by insulin levels of around $40 \mathrm{mU} / 1$, which suggests that hepatic sensitivity to insulin is normal [7] and that glucose over-production does not contribute to the glucose intolerance of these insulin-treated diabetic subjects.

In this study somatostatin was used only in the control subjects because our Type 1 diabetic patients did not secrete insulin in response to hyperglycaemia (Table 2). It has been previously shown that somatostatin per se, has no direct effects on in vivo or in vitro glucose production or utilization, apart from its effects through changes in insulin and glucagon levels [23-26]. In the present protocol insulin was infused in both groups, but glucagon was not replaced. However, glucagon does not alter peripheral glucose utilization [27] and therefore differences in glucagon concentrations between control and diabetic subjects would not have affected peripheral glucose utilization.

Finally, these data confirm that, in normal individuals, the removal of glucose from plasma post-prandially 
is due to the combined effects of hyperglycaemia and a modest rise in insulin [28]. In contrast, in our diabetic patients, hyperglycaemia resulted in only a small rise in the rate of glucose uptake, despite the comparable degree of hyperinsulinaemia to control subjects (Figs. $2 \mathrm{~A}$ and B). In fact, the defect in glucose utilization was not corrected by acute, large elevations of plasma free insulin (Fig. 2A). The latter abnormality would result therefore in higher and more prolonged elevations of blood glucose occurring post-prandially in many diabetic subjects, regardless of the circulating free insulin levels.

It is concluded that poorly controlled insulin-dependent diabetics have a marked defect in glucose utilization that cannot be corrected by short-term hyperinsulinaemia. Further studies are required to determine whether this defect in glucose disposal persists after a period of strict metabolic control.

Acknowledgements. J.Proietto and A. Nankervis were recipients of National Health and Medical Research Council Research Scholarships. For J. Proietto this work was performed in partial fulfilment of the Thesis requirement. This work was supported by the National Health and Medical Research Council of Australia and the John Claude Kellion Foundation. We wish to thank the staff of St.Vincent's Hospital Biochemistry Department for the technical assistance, and Novo Laboratories (Australia) for financial assistance with the purchase of somatostatin. We are grateful to Ms. K. Dawson for her assistance in the preparation of this manuscript.

\section{References}

1. Soskin S, Levine R (1937) A relationship between the blood sugar level and the rate of sugar utilization, affecting the theories of diabetes. Am J Physiol 120: 761-770

2. Soskin S, Levine R (1940) On the mode of action of insulin. Am J Physiol 129: 782-786

3. Proietto J, Harewood M, Aitken P, Nankervis A, Caruso G, Alford $F$ (1982) Validation of a practical in vivo insulin dose-response curve in man. Metabolism 31:354-360

4. DeFronzo RA, Tobin JD, Andres R (1979) Glucose clamp technique: a method for quantifying insulin secretion and resistance. Am J Physiol 237 (3): E214-223

5. Proietto J, Alford FP, Dudley FJ (1980) The mechanism of the carbohydrate intolerance of cirrhosis. J Clin Endocrinol Metab 51: 1030-1036

6. Steele R, Wall JS, de Bodo RC, Altszuler N (1956) Measurement of size and turnover rate of body glucose pool by isotope dilution method. Am J Physiol 187: 15-24

7. Rizza RA, Mandarino LJ, Gerich JE (1981) Dose response characteristics for effects of insulin on production and utilization of glucose in man. Am J Physiol 240: E630-639

8. Albano JDM, Akins RP, Maritz G (1972) A sensitive, precise radioimmunoassay of serum insulin relying on charcoal separation of bound and free hormone moieties. Acta Endocrinol 70: 487-509

9. Nakagawa S, Nakayama H, Sasaki T, Yoshino K, Ying Yu Y, Shinosaki K, Aoki S, Mashimo K (1973) A simple method for the determination of serum free insulin levels in insulin-treated patients. Diabetes 22: 590-600

10. Heding LG (1975) Radioimmunological determination of C peptide in serum. Diabetologia 11: 541-548

11. Carruthers M, Young DAB (1973) Free fatty acid estimation by a semi-automated fluorometric method. Clin Chim Acta 49: 341-348
12. Williamson DH, Mellanby J, Krebs HA (1962) Enzymic determination of $\mathrm{D}(-)-\beta$-hydroxybutyric acid and acetoacetic acid in blood. Biochem J 82:90-96

13. Steele R (1959) Influences of glucose loading and of injected insulin on hepatic glucose output. Ann NY Acad Sci 82: 420-430

14. Ginsberg HN (1977) Investigation of insulin sensitivity in treated subjects with ketosis-prone diabetes mellitus. Diabetes 26: 278-283

15. DeFronzo RA, Hendler R, Simonson D (1982) Insulin resistance is a prominent feature of type I (juvenile onset) diabetes mellitus. Diabetes 31: 795-801

16. Kobayashi M, Olefsky JM (1979) Effects of streptozotocin-induced diabetes on insulin binding, glucose transport, and intracellular glucose metabolism in isolated rat adipocytes. Diabetes 28: $87-95$

17. Karnieli E, Hissin PH, Simpson IA, Salans LB, Cushman SW (1981) A possible mechanism of insulin resistance in the rat adipose cell in streptozotocin-induced diabetes mellitus. Depletion of intracellular glucose transport systems. J Clin Invest 68: 811-814

18. Pedersen O, Hjollund E (1982) Insulin receptor binding to fat and blood cells and insulin action in fat cells from insulin dependent diabetics. Diabetes 31: 706-715

19. Porter JW (1977) Enzyme adaptation to nutritional and hormonal change. In: Dils R, Kidsen J (eds) Regulation of fatty acid and glycerolipid metabolism. Pergamon Press, Oxford New York Toronto Sydney Paris Frankfurt, pp 41-52

20. Galton DJ, Wilson JPD (1971) The effect of starvation and diabetes on glycolytic enzymes in human adipose tissue. Clin Sci 41 : $545-553$

21. Randle PJ, Garland PG, Hales CN, Newsholme EA (1963) The glucose fatty acid cycle. Its role in insulin sensitivity and the metabolic disturbances of diabetes mellitus. Lancet 1: 785-789

22. Goodman MN, Berger M, Ruderman NB (1974) Glucose metabolism in rat skeletal muscle at rest. Effect of starvation, diabetes, ketone bodies and free fatty acids. Diabetes $23: 881-888$

23. Cherrington AD, Chiasson JL, Liljenquist JE, Jennings AS, Keller U, Lacy WW (1976) The role of insulin and glucagon in the regulation of basal glucose production in the postabsorptive dog. $\mathrm{J}$ Clin Invest 58: 1407-1418

24. Cherrington AD, Lacy WW, Chiasson JC (1978) Effect of glucagon on glucose production during insulin deficiency in the dog. $J$ Clin Invest 62: 664-677

25. Jennings AS, Cherrington AD, Liljenquist JE, Keller U, Lacy WW, Chiasson JL (1977) The roles of insulin and glucagon in the regulation of gluconeogenesis in the postabsorptive dog. Diabetes 26:847-856

26. Cherrington AD, Caldwell MD, Dietz MR, Exton JH, Crofford OB (1977) The effect of somatostatin on glucose uptake and production of rat tissues in vitro. Diabetes 26:740-748

27. Pozefsky T, Tancredi RG, Moxley RT, Dupre J, Tobin JD (1976) Metabolism of forearm tissues in man - studies with glucagon. Diabetes 25: 128-135

28. Proietto J, Nankervis A, Aitken P, Caruso G, Harewood M, Alford FP (1983) The physiological action of insulin on glucose uptake and its relevance to the interpretation of the metabolic clearance rate of glucose. Metabolism (in press)

Received: 7 June 1982

and in revised form: 21 July 1983

Dr. J. Proietto

Endocrine Unit

St. Vincent's Hospital

Victoria Parade

Fitzroy, Victoria 3065

Australia 